\title{
PELAYANAN ANGKUTAN UMUM DALAM MENGATASI KEMACETAN DI KUTA
}

\author{
Emma Ratna Sari Moedy \\ Fakultas Ilmu Sosial dan Ilmu Politik Universitas Mahendradatta - Denpasar \\ email: emmamoedy@gmail.com
}

\begin{abstract}
Abstak-Dasar hukum pengelolaan pariwisata menjadi pijakan bagi pelaksanaan pengelolaan daerah wisata, tata ruang dan transportasi yang dapat menunjang suatu daerah wisata. Peran pemerintah dalam mengembangkan pariwisata secara garis besarnya adalah menyediakan infrastruktur (tidak hanya dalam bentuk fisik), memperluas berbagai bentuk fasilitas, kegiatan koordinasi antara aparatur pemerintah dengan pihak swasta, pengaturan, dan promosi umum ke daerah lain maupun ke luar negeri. Pemerintah mempunyai otoritas dalam pengaturan, penyediaan, dan peruntukan berbagai infrastruktur yang terkait dengan kebutuhan pariwisata.Tidak hanya itu, pemerintah bertanggung jawab dalam menentukan arah yang dituju perjalanan pariwisata. Kebijakan yang ditempuh pemerintah merupakan panduan bagi stakeholder yang lain di dalam memainkan peran masing-masing. Saat ini pelayanan transportasi publik belum dapat memberikan jaminan pelayanan yang baik.Persentase pengguna transportasi publik sangatlah sedikit, bahkan kurang dari angka 3\%. Sebagian terbesar para pengguna jalan menggunakan transportasi pribadi, terutama sepeda motor yang kepemilikannya melampaui 70\%. Pengenalan dan pengembangan transportasi publik massal melalui Bus Rapid Transit (BRT) yang diberi label Trans Sarbagita adalah salah satu bentuk upaya untuk mengatasi kemacetan lalu lintas melalui penyediaan palayanan transportasi publik yang lebih baik. Dampaknya adalah akan makin banyak/luas wilayah yang dapat dilayani oleh transportasi publik. Saat ini wilayah-wilayah yang tidak terlayani akan tetap menghasilkan pengguna transportasi pribadi dan akan selalu menjadi sumber kemacetan.
\end{abstract}

\section{Kata kunci: pelayanan publik, kebijakan publik}

ABSTRACT-The legal basis of tourism management becomes the basis for the implementation of the management of tourist areas, spatial planning and transportation that support a tourist area. The role of the government in developing tourism in outline is to provide infrastructure (not only in physical form), expand various forms of facilities, coordinate activities between government officials and the private sector, regulate and promote the general to other regions and abroad. The government has the authority to regulate, supply and designate various infrastructures related to tourism needs. Not only that, the government is responsible for determining the direction of tourism travel. The policy adopted by the government is a guide for other stakeholders in playing their respective roles. At present public transportation services have not been able to guarantee good services. The percentage of users of public transportation is very small, even less than 3\%. The majority of road users use private transportation, especially 
motorcycles whose ownership exceeds $70 \%$. The introduction and development of mass public transportation through Bus Rapid Transit (BRT) labeled Trans Sarbagita is one form of efforts to overcome traffic congestion through the provision of better public transportation services. The impact is that more and more areas will be served by public transportation. At present unserved areas will continue to produce private transportation users and will always be a source of traffic jams.

key word:public services, good governance

\section{Pendahuluan}

Bali sebagai destinasi wisata favorit Indonesia dan dunia memiliki cukup banyak tempat-tempat menarik untuk dikunjungi.Kuta merupakan salah satu destinasi wisata paling favorit bagi para pelancong domestik dan mancanegara.Tingginya minat kalangan wisatawan untuk mengunjungi Pulau Bali khususnya ke wilayah Kuta, membuat akses jalan menuju dan keluar dari Kuta sering kali macet.Dinas Infokom dan Perhubungan Provinsi Bali, menyebutkan bahwa jumlah kendaraan bermotor di Pulau Bali mencapai 5,1 juta unit. Dari jumlah itu yang terdeteksi bernomor polisi Bali hanya sebanyak 3 juta unit. Dari angka 2,1 juta kendaraan bermotor bernomor polisi non Bali tersebut diantaranya merupakan kendaraan para wisatawan yang datang mengunjungi Bali (http://suaradewata.com/read/2016/04/01/20 1604010011/Di-Bali-Kendaraan-BermotorCapai-5-Juta-Unit.html).

Upaya guna mengantisipasi masalah kemacetan yang semakin parah sebagai efek dari makin meningkatnya angka kunjungan wisatawan ke Kuta, maka diperlukan usaha untuk menata kembali kawasan Kuta, baik dari segi tata ruang, transportasi (utamanya transportasi publik) dan kepariwisataannya. Pengelolaan tata ruang dilakukan, utamanya untuk pembangunan jalan baru akan banyak mengalami kendala. Tingginya biaya untuk pembebasan lahan merupakan tantanganyang tidak mudah, apalagi bagi daerah Kuta dengan bangunan fisik yang cukup padat. Hal yang memungkinkan untuk dilakukan adalah pembenahan tranportasi publik, sebagai bagian dari pelayanan kepada publik.Alwi Hasyim Batubara menyebutkan public services menjadi salah satu ukuran dalam penerapan kinerja good governance karena memiliki indikator yang jelas kemanfaatannya oleh semua pihak baik itu negara hadir sebagai pelayan masyarakat termasuk pula publik secara umum, karena muara dari segala kegiatan dan program 
pemerintah daerah tercermin pada seberapa baik kualitas pelayanan yang diberikannya untuk masyarakat (http://repository.usu.ac.id /bitstream/123456789/17995/1/adkmei20063\%20(1).pdf,diakses 8 Desember 2016). Acuan menyusun serta menetapkan Standar Pelayanan Minimal (SPM) yang dapat diterapkan oleh Pemerintahan Daerah Provinsi dan Pemerintahan Daerah Kabupaten/Kota sebagai salah satu ukuran kinerja Pemda tercantum pada Peraturan Menteri Dalam Negeri Nomor 6 Tahun 2007 tentang petunjuk teknis penyusunan dan penetapan standar pelayanan minimal berdasarkan Peraturan Pemerintah Nomor 65 Tahun 2005 tentang Pedoman Penyusunan dan Penerapan Standar Pelayanan Minimal, yang meliputi: 1) Jenis pelayanan dasar yang berpedoman pada SPM, 2) Indikator dan nilai SPM, 3) Batas waktu pencapaian SPM.

Saat ini telah ada transportasi publik yang beroperasi di sekitaran Kuta namun belum dapat beroperasi maksimal karena masih minimnya penumpang. Keengganan masyarakat beralih dari transportasi pribadi ke transportasi publik disebabkan oleh faktor kenyamanan, keamanan, konektifitas yang dinilai masih rendah, ketidaktepatan jadwal keberangkatan, dan biaya tinggi tranportasi
publik.Perihal faktor kualitas dan kuantitas transportasi publik menjadi perlu dikaji jika ingin mengatasi makin tingginya kepadatan lalu-lintas di daerah wisata Kuta.Daerah Kuta yang bukan hanya destinasi wisata domestik namun juga berkelas internasional,seharusnya mempunyai transportasi publik berskala internasional pula.

Salah satu ukuran dalam melihat kinerja pemerintah adalah dengan melihat pada kualitas pelayanan publik. Selama ini kinerja pemerintah dikaitkan dengan birokrat yang mana mengejar protected job security, guna mendapatkan bayaran bulanan yang teratur dan pensiun yang cukup nyaman ketimbang sumber daya manusia berdedikasi yang menghadirkan public goods berkualitas. Memiliki etos bekerja yang sangat hati-hati, membuta pada peraturan, hanya bekerja di belakang meja, dan tidak menyukai tantangan (Muhammad: 2008, 3). Konsep New Public Management mengadopsi teknik-teknik yang dilaksanakan pada sektor privat ke dalam sektor publik sebagai upaya untuk dapat meningkatkan efisiensi dan efektivitas organisasi sektor publik. Ingraham and Kneedler menyebutkan kuncinya sebenarnya pada pengembangan kapasitas manajemen organisasi sebagai 
kunci penjelas untuk kinerja (Muhammad: 2008, 3-4). Dengan semakin menurunnya kepercayaan publik pada pemerintah, terlihat dari sikap warga negara yang tidak percaya pemerintah karena kinerjanya yang buruk.

Dibutuhkan dedikasi pada kebijakan yang telah ditetapkan.Keberhasilan terhadap pelayanan publik sebagai implementasi kebijakan bukan hanya tentang jumlah, keahlian atau pengetahuaan pelaksana dalam melaksanakan fungsi dan tugasnya, namun juga kemauan pelaku kebijakan di dalam pelaksanaan kebijakan.Kemauan, keinginan dan kecendrungan pelaku kebijakan dalam melaksanakan kebijakan dengan sungguhsungguh sehingga tujuan kebijakan tercapai.Penerimaan terhadap standar dan

\section{Tinjauan Kebijakan mengatasi}

Kemacetan dan Pelayanan Transportasi

\section{Publik di Kuta}

Persoalan kemacetan yang mengiringi pesatnya pertumbuhan lokasi wisata pantai Kuta, dapat dianalisis dari aspek:

1. Undang-undang Nomor 10 Tahun 2009 tentang Kepariwisataan (Lembaran Negara Republik Indonesia Tahun 2009 Nomor 11; Tambahan Lembaran Negara Republik Indonesia Nomor 4966; juga tujuan adalah potensi keberhasilan implementasi (Widodo, 2013: 104).

Dalam konsep kebijakan publik berbasis Dynamic Policy Analysis, kebijakan publik dirancang dengan mendasarkan diri pada analis kebijakan yang berani melakukan pemikiran ulang atas desain kebijakan publik yang telah ada.Dibutuhkan alternatif kebijakan yang kreatif dan adaptif terhadap perubahan lingkungan kebijakan secara tepat dan cepat serta pelibatan aktif publik dalam mendefinisikan suatu masalah. Konsep ini bersangkutan dengan sinergitas analisis kebijakan dengan publik, privat, dan pemerintah (Indiahono, 2009: 56 dan 70).
Undang-undang ini dibuat salah satunya dengan menimbang bahwa kepariwisataan merupakan bagian integral dari pembangunan nasional yang dilakukan secara sistematis, terencana, terpadu, berkelanjutan, dan bertanggung jawab dengan tetap memberikan perlindungan terhadap nilai-nilai agama, budaya yang hidup dalam masyarakat, kelestarian dan mutu lingkungan hidup, serta kepentingan nasional; 
2. Peraturan Daerah Provinsi Daerah Tingkat I Bali Nomor 16 Tahun 2009 tentang Rencana Tata Ruang Wilayah Provinsi Bali Tahun 2009-2029. (Lembaran Daerah Provinsi Bali Tahun 2009 Nomor 16, Tambahan Lembaran Daerah Provinsi Bali Nomor 15). Dalam perda ini disebutkan tentang Kawasan Pariwisata didefinisikan sebagai kawasan strategis pariwisata yang berada dalam geografis satu atau lebih wilayah administrasi desa/kelurahan yang di dalamnya terdapat potensi daya tarik wisata, aksesibilitas yang tinggi, ketersediaan fasilitas umum dan fasilitas pariwisata serta aktivitas sosial budaya masyarakat yang saling mendukung dalam perwujudan kepariwisataan. Kawasan Daya Tarik Wisata Khusus, yang selanjutnya disebut KDTWK, adalah kawasan strategis pariwisata yang berada dalam geografis satu atau lebih wilayah administrasi desa/kelurahan yang di dalamnya terdapat potensi daya tarik wisata, aksesibilitas yang tinggi, ketersediaan fasilitas umum dan fasilitas pariwisata secara terbatas serta aktivitas sosial budaya masyarakat yang saling mendukung perwujudan kepariwisataan, namun pengembangannya sangat dibatasi untuk lebih diarahkan kepada upaya pelestarian budaya dan lingkungan hidup.

Pasal 22 dari Perda ini mengatur tentang Rencana Pengembangan Sistem Jaringan Transportasi Darat. Selanjutnya pada ada pasal 25 diatur tentang:

(1) Peningkatan kuantitas dan kualitas pelayanan angkutan umum

(2) Pengembangan angkutan umum mencakup:

a. pengembangan secara bertahap sistem terpadu angkutan umum massal antar kota dan Kawasan Metropolitan Sarbagita yang ramah lingkungan dan menggunakan energi terbarukan;

b. pengembangan sistem trayek terpadu dan terintegrasi baik antar kota, kawasan perkotaan maupun kawasan perdesaan; dan

c. pengembangan kebijakan untuk menekan pemanfaatan terminal khusus pariwisata dalam bentuk sentral parkir di pusat-pusat kawasan pariwisata yang telah berkembang.

Dasar hukum pengelolaan pariwisata menjadi pijakan penting bagi pelaksanaan pengelolaan daerah wisata, tata ruang, dan 
transportasi yang menunjang suatu daerah wisata.Pemerintah memiliki peran dalam pengembangan pariwisata.Peran pemerintah di dalam mengembangkan pariwisata secara garis besar adalah menyediakan infrastruktur (tidak saja dalam bentuk fisik), memperluas berbagai bentuk fasilitas-fasilitas, kegiatan koordinasi antar aparatur pemerintah dengan pihak swasta, pengaturan sekaligus promosi umum ke daerah lain maupun ke luar negeri. Pemerintah mempunyai otoritas dalam pengaturan, penyediaan, dan peruntukan berbagai infrastruktur yang terkait dengan kebutuhan pariwisata.Tidak hanya itu, pemerintah bertanggung jawab dalam menentukan arah yang dituju perjalanan pariwisata.Kebijakan yang ditempuh pemerintah merupakan panduan bagi stakeholder yang lain di dalam memainkan peran masing-masing. Pemerintah sejauh mungkin bisa mengikutsertakan masyarakat setempat dan stakeholder lainnya dalam perencanaan dan pengembangan.

Sudah saatnya Bali memiliki sistem transportasi publik berkelas internasional, agar cocok dengan citra Bali di dunia modern.Kalkulasi ekonomis pembangunan transportasi publik berkelas internasional memang memerlukan biaya yang sangat besar.Namun, kemanfaatannya yang sangat besar menjadikan pembangunan transportasi publik ini harus diperjuangkan.

Sebelumnya, Gubernur Bali I Made Mangku Pastika dalam acara Lokakarya Pengembangan Transportasi Perkotaan, 20 November 2013, mengatakan bahwa pengembangan transportasi publik menjadi keniscayaan bagi sebuah kota metropolitan yang kebanyakan tersandera terkait masalah kemacetan. Pengembangan transportasi oleh pemda sering terhambat oleh kebutuhan investasi yang cukup besar. Pemprov Bali membutuhkan dukungan dana sebesar Rp60,3 miliar pada tahun-tahun mendatang untuk pengembangan transportasi publik. Adapun pada 2015, kebutuhannya lebih kecil, yaitu Rp54,6 miliar. Perbandingan kebutuhan investasi di Surabaya untuk pengembangan transportasi publik mencapai Rp6,42 triliun pada 2014 sampai 2016. Sementara itu, Pemkot Surabaya sendiri hanya mampu menyediakan pembiayaan sebesar Rp2,74 triliun.

Provinsi Bali memiliki persoalan transportasi yang sangat berat dan kompleks.Untuk transportasi darat, bila dilihat dari skala makro, ada dua kondisi umum yang perlu mendapatkan perhatian. Pertama adalah yang terkait dengan kondisi lalu lintas (traffic) dan kedua adalah kondisi 
angkutan (transport). Saat ini pelayanan transportasi publik belum dapat memberikan jaminan pelayanan yang baik.Persentase pengguna transportasi publik sangat sedikit, bahkan kurang dari 3\%. Sebagian terbesar para pengguna jalan menggunakan transportasi pribadi, terutama sepeda motor yang kepemilikannya melampaui $70 \%$. Pengenalan dan pengembangan transportasi publik massal melalui Bus Rapid Transit (BRT) yang diberi label Trans Sarbagita adalah salah satu bentuk upaya untuk mengatasi kemacetan lalu lintas melalui penyediaan pelayanan transportasi publik yang lebih baik (Bisnis: 2015). Dampaknya adalah akan makin banyak atau luas wilayah yang dapat dilayani transportasi publik. Saat ini wilayah-wilayah yang tidak terlayani akan tetap menghasilkan pengguna transportasi pribadi dan akan selalu menjadi sumber kemacetan. Pemerintah harus segera menyediakan investasi dalam transportasi publik. Jika pilihan untuk bertransportasi cukup banyak dan terjangkau maka secara otomatis akan terjadi pengurangan penggunaan kendaraan pribadi, karena mereka akan serta merta beralih ke transportasi publik termasuk di daerah wisata.

Pemerintah berperan mengedukasi masyarakat akan pentingnya transportasi publik. Sehingga transportasi publik menjadi pilihan utama selain kendaraan pribadi, sekaligus membudayakannya di tengahtengah masyarakat.Transportasi publik yang telah ada dapat dimaksimalkan pelayanan, kenyamanannya ditingkatkan, hargalebih terjangkau, aksesabilitas, dan keamanannya sehingga orang tertarik menggunakannya.

Masalah kemacetan sudah mengakar di daerah pariwisata.Penyebabnya sangat kompleks sehingga dibutuhkan penanganan yang komprehensif jadi tidak hanya diatasi dari satu sisi saja. Sinergi pemerintah, swasta dan masyarakat sangat dibutuhkan agar dunia transportasi Bali ke depan harus dapat memberijaminan terhadap kelancaran, kepastian, kenyamanan, keterjangkauan, dan keselamatan yang lebih baik. Hal ini hanya akan dicapai apabila konsep perencanaannya benar, pelaku-pelaku (stakeholders) bersatu padu, kebijakan pemerintah mendukung, ketaatan masyarakat tinggi dan penerapan enforcement yang tegas. Kontinuitas dan keterpaduan antarmoda transportasi juga merupakan bagian yang menjadi syarat untuk menjadikan tingkat kualitas yang lebih baik. Dengan demikian akan dapat dicapai efektivitas dan efisiensi yang pada akhirnya akan dapat mendukung upaya mengatasi kemacetan. Persoalan menyangkut lalu lintas dan transportasi publik merupakan 
cerminandari wajah Bali sebagai destinasi wisata dunia. Bali harus belajar dari daerah lain di Indonesia, maupun kota-kota besar di dunia dalam menangani masalah transportasinya, tentu saja diadaptasi dengan kondisi sosial budaya masyarakat Bali, sehingga mampu menentukan alternatif yang baik pengadaan transportasi publik, khususnya di daerah rawan kemacetan seperti di daerah wisata Kuta.

\section{DAFTAR PUSTAKA}

\section{A. Buku/ Jurnal}

Indiahono, Dwiyanto. 2009. Kebijakan Publik Berbasis Dynamic Policy Analysis. Gava Media. Yogyakarta.

Muhammad, Fadel. E-book: Reinventing Local Government untuk Memberdayakan Birokrasi Pemerintah Daerah.----------. 2006. Mempraktekkan Entrepreneurial Government. Pustaka Indonesia Press. Jakarta

Widodo, Joko. 2013. Analisis Kebijakan Publik: Konsep dan Aplikasi Analisis Proses Kebijakan Publik. Bayumedia Publishing. Malang.

\section{B.Internet}

http://dishubinkom.baliprov.go.id/id/ANGK UTAN-UMUM-Trans-SARBAGITA http://repository.usu.ac.id/bitstream/123456 789/17995/1/adk-mei2006-3\%20(1).pdf http://suaradewata.com/read/2016/04/01/201

604010011/Di-Bali-KendaraanBermotor-Capai-5-Juta-Unit.html
Alternatif terbaik di dalam mengatasi kemacetan tersebut dapat menjadi sebuah kebijakan baru yang berhasil apabila implementasinya didukung oleh semua elemen stakeholders mulai dari pemerintah sebagai pengambil kebijakan, pelaku usaha pariwisata, wisatawan, masyarakat lokal dan investor tentu dengan tetap mempertahankan budaya dan kearifan lokal Bali.

\section{C.Peraturan Perundang-undangan}

Undang-Undang Nomor 22 Tahun 2009 tentang Lalu Lintas dan Angkutan Jalan

Peraturan Menteri Dalam Negeri Nomor 6 Tahun 2007 tentang Petunjuk Teknis Penyusunan dan Penetapan Standar Pelayanan Minimal

Peraturan Pemerintah Nomor 65 Tahun 2005 tentang Pedoman Penyusunan dan Penerapan Standar Pelayanan Minimal

Undang-undang Nomor 10 Tahun 2009 tentang Kepariwisataan

Peraturan Daerah Provinsi Daerah Tingkat I Bali Nomor 16 Tahun 2009 tentang Rencana Tata Ruang Wilayah Provinsi Bali Tahun 2009-2029 